family by all succeeding authors. Philippi also describcd and figured it as new under the name of Thyreus Paradoxus, Supp. 92. t. 18. f. 11 .

Having lately obtained a fresh specimen with the animal dried in it, I soaked it in water, and on comparing the remains of the animal with other genera, I believe that the Pedicularia of Swainson should be placed next to Concholepas, if it is more than a section of that genus, for it only differs from that genus in having no tooth-like process on the front of the outer lip, and in the edge of the outer lip being generally sinuous, and the inner or columellar lip being rounded, callous, and covering part of the left side of the last whorl. There is a small white shell in Mr. Cuming's collection from the Philippines which has similar characters, but it is even more like the typical Concholepas than Pedicularia Sicula of Swainson.-J. E. GraY.

\title{
Descriptions of some new species of Indian Lizards.
}

$$
\text { By J. E. GraY, Esq. }
$$

Mr. Jerdon of Madras having kindly sent to the Museum a. series of specimens of Indian reptiles, I hasten to describe the following species, which have not before occurred to me, and consequently are not described in my recent Synoptic Catalogue of Reptiles in the British Museum.

\section{Fam. Geckotide.}

Goniodactylus indicus.-Brown, darker marbled and spotted; scales of body and tail small, equal, six-sided; of underside of tail rather larger, six-sided; lower lip-shield $5 \cdot 1 \cdot 5$, square, front larger, equal, rest gradually smaller, last very small.

Hab. Madras. Brit. Mus.

These were accompanied by four species of Hemidactylus.

\section{Fam. Agamides.}

Calotes viridis. Nape with two isolated spines above the ears. Neck without any pit in front of the shoulder, but with dark spots at the hinder part of the lower jaw ; eyebrows not horned. Green; scales large, of base of tail larger, of limbs and underside of the body smaller, of crown smaller. Nape and shoulders with a compressed crest; hinder part of back and tail with an obscure keel.

Hab. Madras. Brit. Mus.

Like $C$. versicolor, but uniformly coloured, the back less crested, and the scales smaller.

Salea Jerdonii. The nuchal and dorsal crest formed of elongated compressed scales; tail with a keeled crest. Blackish, white spotted, spot forming distant cross-bands; lips and beneath white.

Hab. Madras. Brit. Mus.

This genus is best distinguished from Calotes by the length and acuteness of the keeled scales of the back, side and under part of body, and their being all placed in longitudinal series. The other species has only the nape shortly crested. 
Draconella Dussumieri, Gray, Syn. Rept. Brit. Mus. 234; Sitana Ponticeriana, Cuv., Gray, l. c. 236; and Charasia dorsalis, Gray, l. c. 246, were also contained in the collection.

\section{Fam. Scincidas.}

Mocoa bilineata. Fronto-parietal plates two, separate; ears round, moderate, with two very indistinct minute scales in front; the drum sunken; scales six or eight-rowed, very thin, smooth. Olive, with two black streaks, sides above blackish, beneath pale; cheek dark white, spotted; chin and beneath white. Young paler.

Hab. Madras. Brit. Mus.

Most allied to Mocoa africana, Cat. Rept. Brit. Mus. 83, from West Africa.

Riopa albopunctata. Pale olive-brown, yellowish beneath; sides of the head and of the front half of the body blackish, minutely white dotted.

Hab. Madras. Brit. Mus.

Tiliqua pulchra, Gray, Illust. Ind. Zool. t. f. 2, from General Hardwicke's drawing may be intended for this species, but it looks too fusiform.

Riopa Hardwickii, Gray, Syn. Rept. Brit. Mus. 96.

Hab. Madras. Brit. Mus.

Tiliqua rubriventris, Gray, Illust. Ind. Zool. 9. tab. f. 1. Olive, with a few scattered black spots; beneath yellowish white; temples, sides and limbs with white-eyed black spots; scales three-keeled.

$H a b$. Madras. Before only known from GeneralHardwicke's drawing, which did not represent the scales as keeled.

Euprepis trilineata. Fronto- and interparietals separate, scales five-keeled. Pale olive, with white-eyed brown spots; head and front half of the body with three dark-edged pale streaks; lips and beneath yellow; ears with two elongated scales in front.

$H a b$. Madras. Brit. Mus.

This species is distinct from Tiliqua trivittata, Gray, Illust. Ind. Zool. tab. , figured from General Hardwicke's drawings, but still unknown in Europe.

Description of Unio abacoides, a new species. By S. S. Haldeman.

Shell subovate, obtusely and regularly rounded posteriorly; discs approximate, chestnut-brown and pale green, with green radiating interrupted capillary lines, and a tendency to form a submedial nodulous ridge: primary teeth robust, their inner margin nearly at right angles with the short lamellar teeth : pallial and muscular impressions well-marked: nacre white, roseate posteriorly.

Length $2 \frac{5}{8}$ inches; height 2 ; diameter $1 \frac{1}{8}$.

Allied to $U$. dromas, Lea, and $U$. intermedius, Conrad, but proportionally longer than either. In its outline and small transverse diameter it resembles $U$. abacus. I am indebted for this interesting shell to the liberality of Dr. Foreman, who received it from Eastern Tennessee._Silliman's American Journal, Sept. 1846. 


\section{$2 \mathrm{BHL}$ Biodiversity Heritage Library}

Gray, John Edward. 1846. "Descriptions of some new species of Indian Lizards." The Annals and magazine of natural history; zoology, botany, and geology 18, 429-430. https://doi.org/10.1080/037454809494450.

View This Item Online: https://www.biodiversitylibrary.org/item/19556

DOI: https://doi.org/10.1080/037454809494450

Permalink: https://www.biodiversitylibrary.org/partpdf/23296

\section{Holding Institution}

Natural History Museum Library, London

\section{Sponsored by}

Natural History Museum Library, London

\section{Copyright \& Reuse}

Copyright Status: Public domain. The BHL considers that this work is no longer under copyright protection.

This document was created from content at the Biodiversity Heritage Library, the world's largest open access digital library for biodiversity literature and archives. Visit BHL at https://www.biodiversitylibrary.org. 